\title{
Review of research in photovoltaic panels cooling for domestic and industrial applications
}

\author{
Mehmet Ali Yildirim ${ }^{1 *}$, and Artur Cebula ${ }^{1}$ \\ ${ }^{1}$ Cracow University of Technology, Energy Department, 31-864 al. Jana Pawła II 37, Cracow, Poland
}

\begin{abstract}
This paper presents a review of recent photovoltaic cooling technologies and techniques used to reduce the negative impact of increased temperature to enhance the production of electricity by photovoltaic (PV) modules. Various cooling methods are reviewed; namely, Thermoelectric cooling, PV cooling with phase change materials (PCM) and nanofluids, PV systems cooled by forced water circulation, water immersion cooling technique, PV systems cooled by heat sinks, and solar PV systems cooled by water spraying. Several research papers are reviewed, and their focus is explained to provide an understanding of each cooling method to decrease the surface temperature of PV modules. In the conclusion section, the advantages and disadvantages of the above-mentioned cooling methods are expressed. This work can be used by engineers working on the design and theory of cooled photovoltaic systems.
\end{abstract}

\section{Introduction}

Limited sources of fossil fuels and their environmental impact, renewable energy systems are needed. The recent advancements in renewable energy technology have led to a steady declining trend of the Levelized Cost of Electricity (LCOE). One of the most widespread technologies of clean energy generation is photovoltaic (PV) systems that convert direct sunlight radiation to electricity. $\mathrm{PV}$ technology is more and more authenticated with its practical and efficient solutions with reduced emissions of greenhouse gases [1-3]. The cost of operation and production will continue to decrease with the latest advancements in PV technology. LCOE of PV systems will be low as 33.12 USD/MWh in 2025 , according to a report published by U.S. Energy Information Administration.

The power from the sun received by the earth is about $1.8 \times 10^{11} \mathrm{MW}$ of solar energy is 1000 times greater than power being consumed from all sources making solar energy a more attractive, inexhaustible, and ecofriendly source of energy [4]. Furthermore, the produced energy can be incorporated in applications with heating and desalination processes [5]. On the other hand, the PV cells can absorb $80 \%$ of the sunlight falling on their surface. However, the electricity conversion efficiency is currently between $12 \%$ and $18 \%$. The rest of the solar energy is converted into heat, raising the PV cell temperature. The general factors affecting the electricity conversion efficiency are operating temperature, hail, dust, humidity, and solar irradiance [6, 7]. At high temperature, carrier concentrations of $\mathrm{p}-\mathrm{n}$ junction increases and causes the decrease of PV efficiency [8]. The increase of the PV module temperature results in a decrease in open-circuit voltage $(V o c)$ and a drop in efficiency. In [9, 10], it can be found that the temperature increase of every $1^{\circ} \mathrm{C}$ of $\mathrm{PV}$ module causes a decrease of $0.2-0.5 \%$ electrical efficiency. The effect of temperature on PV cell voltage, current, and power is illustrated in Figures 1 and 2.

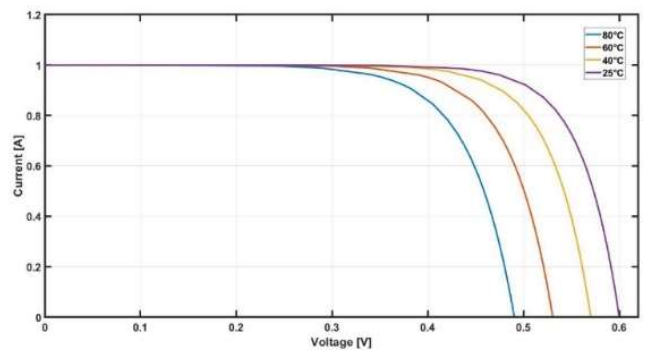

Fig. 1. Effect of temperature on I-V characteristic of PV cell

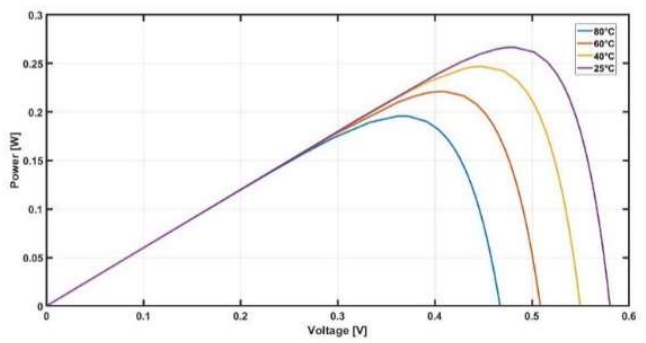

Fig. 2. Effect of temperature on P-V characteristic of PV cell

As shown from the above figures, one of the significant problems in electricity production is high operating temperature. In order to accomplish more effective and efficient electricity production than conventional systems, PV systems are thermally managed. Therefore, many researchers are focused on

\footnotetext{
* Corresponding author: mehmet.yildirim@doktorant.pk.edu.pl
} 
the high operating temperature effect and tried to overcome its adverse effects [11-15].

Many authors have tried to conduct an extensive review of cooling methods. In [16], PV cooling techniques were briefly discussed. The main focus of the paper was testing a Ground-Coupled Central Panel Cooling System. The authors presented various cooling techniques in [17]. However, the paper only examined forced air and liquid forced convection and passive cooling methods applied to solar concentrator systems.

This paper aims to provide a comprehensive review of different cooling technologies to minimise the negative effect of the temperature on PV modules. The following techniques will be analysed in this work: PV panel with thermoelectric cooling [18], PV cooling with phase change material (PCM) [19-21], and nanofluids [22, 23], PV cooled by forced water circulation [24, 25], PV panel with water immersion cooling technique [26, 27], water spraying cooling technique [28, 29], and PV cooled by heat sinks [30-32].

This review paper is organised as: in section 2, a singlediode model of PV cell illustrated along with PV system operation briefly. Thus the negative effect of temperature is clearly explained in this section. The importance of cooling with different cooling technologies is explained in section 3. Furthermore, in the conclusion section, the main findings on different cooling techniques are expressed.

\section{Photovoltaic system operation}

When a PV cell is exposed to particles of light, it uses a photovoltaic effect to convert the energy of photons to electrical energy. In order to understand the PV cell's working principle, there are different topologies available. One of them is a single-diode model and is shown in Figure 3.

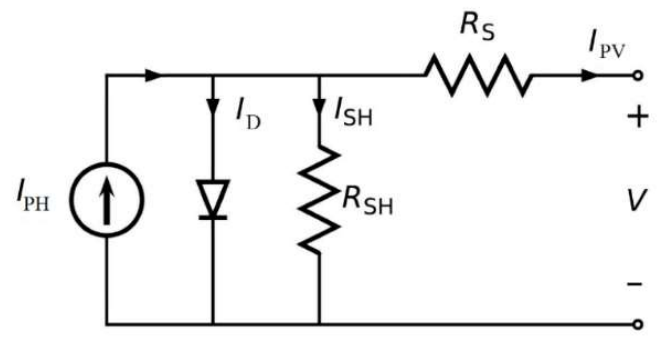

Fig. 3. A single-diode model of PV cell [33]

The detailed electrically equivalent model of PV cell and its formulation can be found in [33]. The surface temperature plays a crucial role in PV cell performance. Figure 3 shows that the temperature range for $\mathrm{PV}$ cell operation ranging from $0^{\circ} \mathrm{C}$ to $75^{\circ} \mathrm{C}$. High temperature causes a decrease in efficiency radically, and it can be seen in Figure 2. The effect of the temperature on PV panel efficiency can be investigated by using the following expression.

$$
\eta_{P V}=\eta_{P V_{R E F}}\left[1-\varepsilon_{r e f}\left(T_{P V_{\text {cell }}}-T_{\text {ref }}\right)\right]
$$

where: $\eta_{P V_{R E F}}$ is the reference PV panel electrical efficiency, provided by the manufacturer, $T_{r e f}$ is the reference cell temperature $\left(25^{\circ} \mathrm{C}\right) . \varepsilon_{r e f}$ indicates the temperature coefficient of PV cells (typically 0.004$0.005 /{ }^{\circ} \mathrm{C}$ ) [34]. In order to understand clearly the effect of temperature, the ambient temperature $T_{a m b}$ is added and subtracted from two terms, respectively. The following formula is obtained [34].

$\eta_{P V}=\eta_{P V_{R E F}}\left[1-0.9 \varepsilon_{r e f}\left(\frac{I_{P V}}{I_{P V_{N}}}\right)\left(T_{P V_{\text {cell, }}}-T_{A, N}\right)-\varepsilon_{r e f}\left(T_{A}-T_{P V_{c e l l}}\right)\right]$ (2)

where $I_{P V}$ indicates average hourly irradiation incident on PV panel at nominal operating temperature. $T_{P V_{\text {cell,N }}}$ and $T_{A, N}$ represent cell and ambient temperatures. It can be seen from Equation 2 when the $T_{A, N}$ increases, the efficiency decreases.

\section{Photovoltaic cooling techniques}

\subsection{Thermoelectric cooling technique}

A thermoelectric generator (TEG) consists of a ptype semiconductor and an n-type semiconductor. TEGs directly convert temperature differences to an electric voltage. The structure of a TEG module is shown in Figure 4.

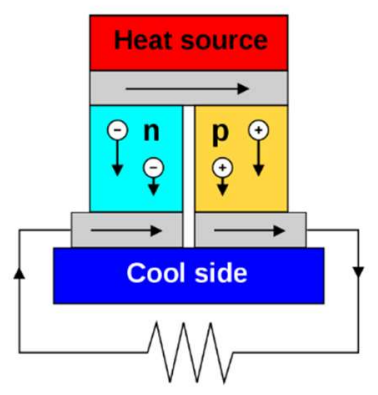

Fig. 4. TEG module structure

The n-type semiconductor and p-type semiconductor are connected in series electrically and in parallel thermally. In this type of cooling, TEGs have installed the backside of the PV panel. During the cooling, TEG current increases, and the cooling effect increases. In order to have adequate cooling, a heat sink is placed for excess heat dissipation. The thermoelectric cooling system can be seen in Figure 5.

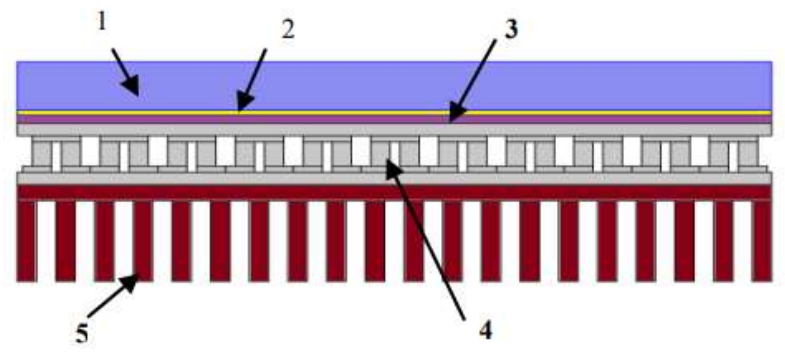

Fig. 5. Thermoelectric cooling [35]

In Figure 5. the numbers indicate the following:

1-Glass cover

2-PV cells

3-Insulator 


\section{4-TEG module}

\section{5-Heat sink}

The numerical investigation and experimental study of the TEG cooling technique can be found in [36] and [37], respectively. The experimental setup of the technique is shown in Figure 6.

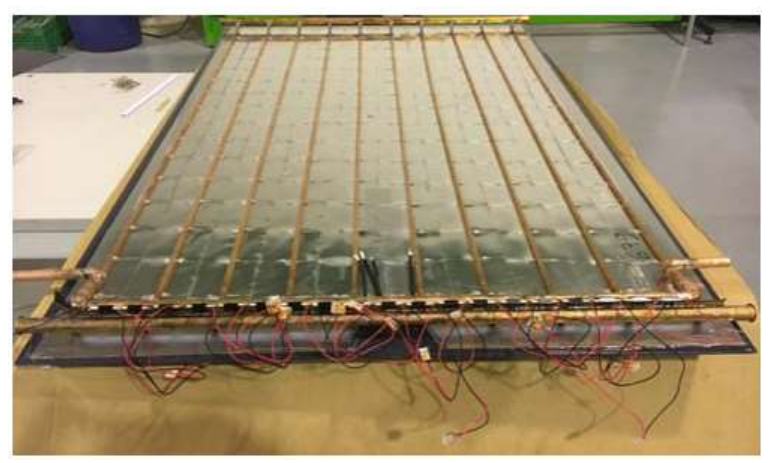

Fig. 6. Experimental setup of thermoelectric cooling [37]

\subsection{Photovoltaic cooling with PCM and nanofluids}

One of the techniques is to use PCMs to reduce the operating temperature of PV modules in order to reach higher electrical efficiency. A phase change material is a substance that absorbs or releases energy at phase change in order to provide cooling or heating. PCMs are latent heat energy storage, and PCM's high latent heat capacity helps to maintain the PV Panel temperature at constant temperatures. The principle is that when the temperature of PCM increases, the phase change occurs, and during the transition, PCM absorbs heat due to the endothermic process. The solar-aided latent heat storage system is investigated in [38]. The structure of the PV cooled by the PCM technique is illustrated in Figure 7.

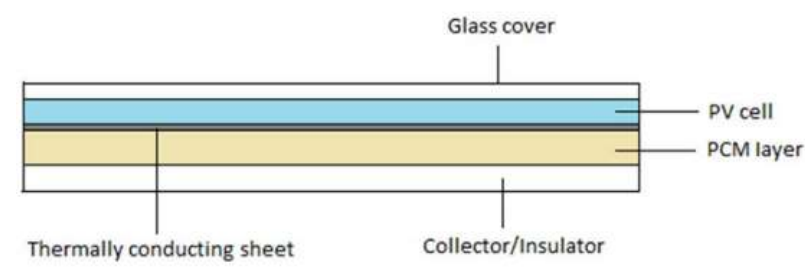

Fig. 7. PCM cooling [39]

A developed 2-D finite volume heat transfer model and the experimental study of PV cooling with PCM can be found in [40]. Microencapsulation of phase change materials with binary cores and calcium carbonate shells for thermal energy storage is proposed [41]. Mass loss of the microcapsules is between $28 \%$ and $5 \%$ when they are heated to $300^{\circ} \mathrm{C}$. Results show that the thermal conductivities of the micro-PCMs are enhanced significantly. Another experimental study is shown in Figure $8 \mathrm{a}, \mathrm{b}$, and the detailed investigation can be found in [42].
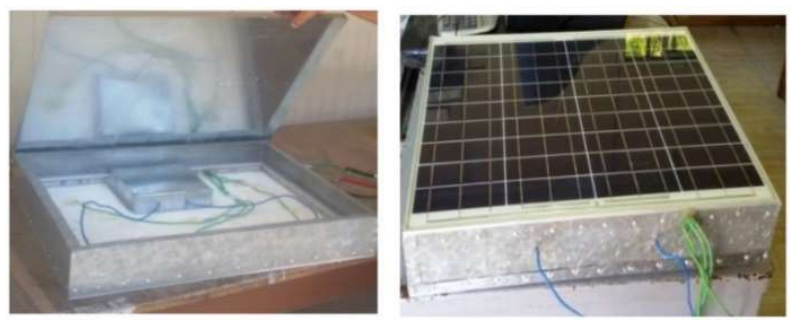

Fig. 8. a) PCM box b) PV-PCM connection [42]

In this experimental setup, PCM box integrated with stand free and building integrated PV module and tested in an outdoor condition of Giza, Egypt. Results show an enhancement in electrical conversion efficiency for both systems.

Another technique is using nanofluids to decrease the surface operating temperature of PV modules. The nanometer-sized Boehmite particles within the size of 5$10 \mathrm{~nm}$ and $99.9 \%$ purity are used in [43]. In this experimental work, under the PV module, two different geometry of the channel system is used, as shown in Figure 9a,b.

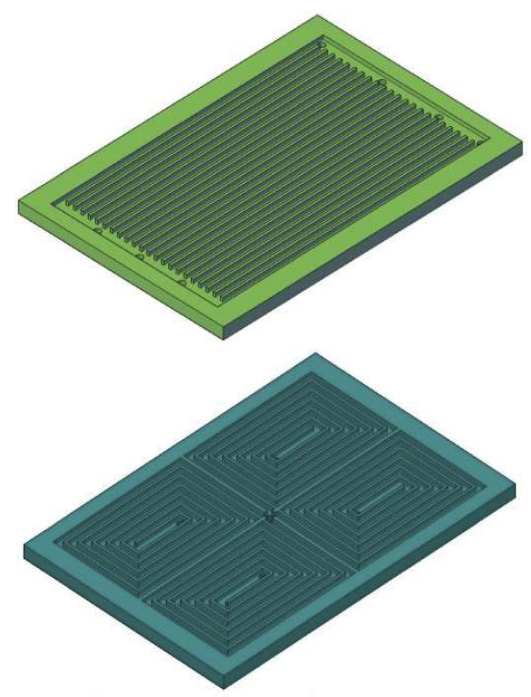

Fig. 9. a) Straight b) Helical [43]

Using the water-based nanofluid and testing with different geometries, the authors achieved an average reduction of temperature relative to a reference temperature of $18.33{ }^{\circ} \mathrm{C}$ and $24.22{ }^{\circ} \mathrm{C}$, respectively, for straight and helical construction.

\subsection{Photovoltaic modules cooled by forced water circulation}

Another technique that can be used to cool down PV modules is the use of forced water circulation. This system consists of a PV panel and channels for water circulation under the PV panel. There are different approaches for implementing forced water circulation. Some authors [44] constructed cooling channels above the PV panel, which is illustrated in Figure 10. In this work [44], the effect of inlet water temperature, mass flow rate, cooling channel height, and solar radiation intensity is investigated. The results show that the optimal value of mass flow rate $0.003 \mathrm{~kg} / \mathrm{s}$, and the height of the cooling channel is $5 \mathrm{~mm}$ with an exergy 
efficiency of $13.8 \%$. In addition, the system presented above has higher thermal efficiency than traditional systems; however, having the cooling system above of PV panel causes a loss in electrical efficiency.

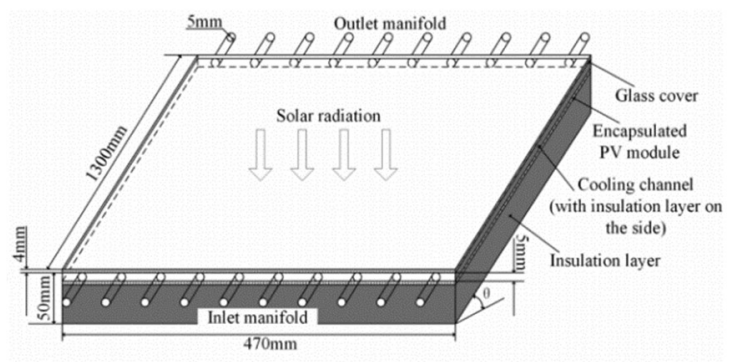

Fig. 10. Construction of PV cooling [44]

In [45], the authors implemented the cooling construction to the back surface of the PV panel in order to evaluate the performance of the PV module. The experimental setup of the system is shown in Figure 11.

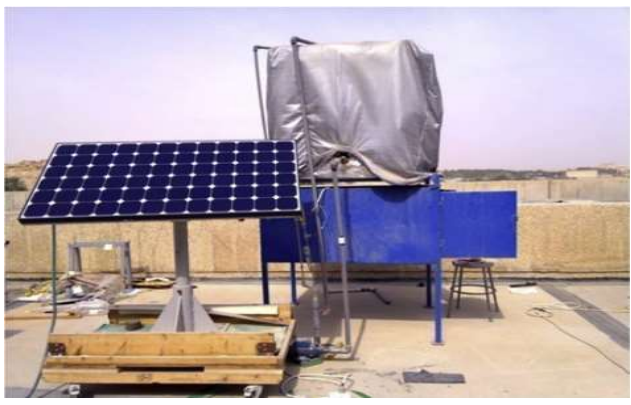

Fig. 11. Experimental setup for cooling the PV module [45]

In this work [45], the cooling water is stored in an insulated tank, and a water pump is used to circulate the water in the system. According to the experiment, the maximum value of radiation received is $979 \mathrm{~W} / \mathrm{m}^{2}$, whereas the average radiation is $710 \mathrm{~W} / \mathrm{m}^{2}$. Results show that the implemented cooling system has reduced the temperature of PV cells by $19.3 \%$. In addition, this value rises to $34 \%$ for the back surface of the PV module. With this active cooling, the authors achieved a $9 \%$ increase in the electrical power yield over the day.

\subsection{Photovoltaic panel with water immersion cooling technique}

The water immersion cooling technique is one of the methods to reduce the operating temperature of the PV module, as seen in Figure 12.

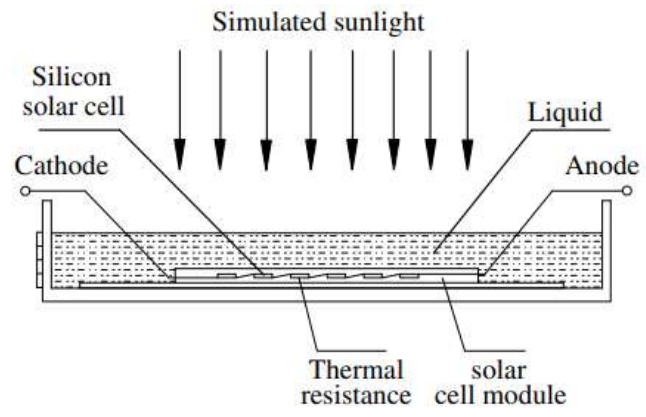

Fig. 12. Schematic of the PV module immersed in liquids system [27]
Using this method, PV modules are placed in large water bodies like oceans, lakes, and rivers. Water is mainly used as an immersion liquid that absorbs heat from the PV module. Furthermore, after absorption of waste heat from the PV, the electrical efficiency of the module increases. In [27], six different fluids are tested as an immersion liquid: polar ethanol and glycerine, inorganic distilled water and tap water, non-polar benzene, and silicon oil. The thickness of the cover films is chosen to be between $3 \mathrm{~mm}$ and $9 \mathrm{~mm}$. According to the results, the PV module immersed in different liquids shows similar results, and it is concluded that there is no direct relationship between the performance of the PV module and the used liquid for immersion. However, the short-circuit current (ISC) is affected by the light intensity onto the module. In the experiment, it is observed that $I_{S C}$ shows certain changes in the thickness of the cover film. The thicker the cover film thickness, the lower the $I_{S C}$ is obtained.

Another experiment is conducted in [46]. The authors analysed the performance of the PV module, which is submerged in water at different depths and can be seen in Figure 13. The depths are ranging between 0 $\mathrm{cm}$ and $6 \mathrm{~cm}$. The results indicate that the electrical efficiency is enhanced by $17.8 \%$ of the submerged PV panel with a depth of $1 \mathrm{~cm}$.

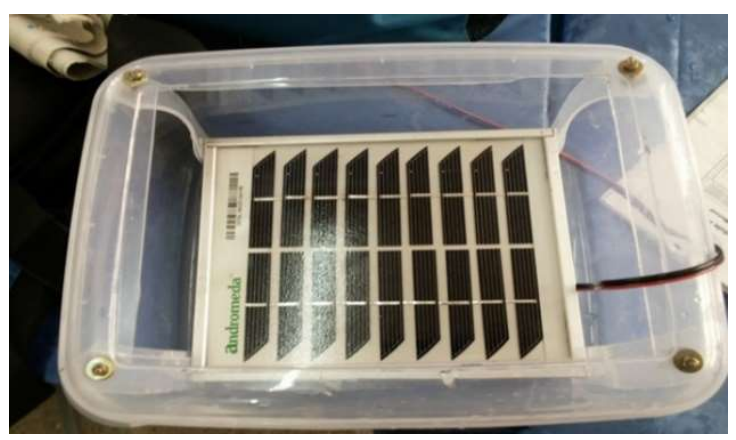

Fig. 13. PV module immersed in water [46]

\subsection{Water spraying cooling technique}

In this method, water spraying nozzles are used to reduce the operating temperature of the PV module. A pump is used to force the water flow through nozzles. In [29], the authors designed a micro-controller-based control water spraying system to cool down the PV module on the front surface. Two PV panels are tested during the experiment, with one of them equipped with a water spraying cooling system. The results show that the electrical conversion efficiency is enhanced by $16.65 \%$. 


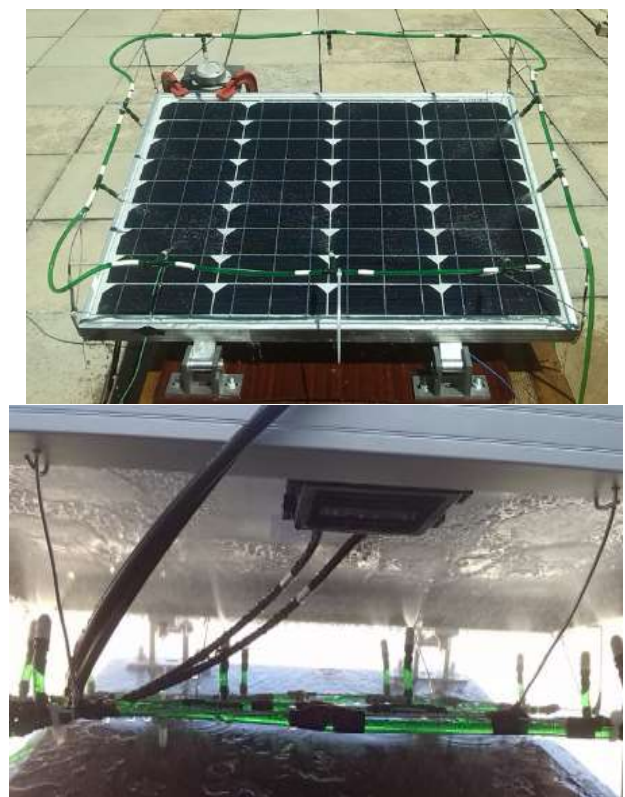

Fig. 14. The water spraying cooling of PV module [47]

Another experimental study is conducted using the water spraying cooling method in [47]. The authors equipped the PV module with a system of spraying nozzles mounted to the back and front sides, as shown in Figure 14.

This study's main goal is to increase heat rejection from the PV module as in other cooling techniques. According to the results, the maximal electrical efficiency is increased by $15.97 \%$.

\subsection{Photovoltaic cooling using heat sinks}

In this type of cooling technique, heat sinks are used for heat rejection from the PV modules. Indoor experiments are conducted using a heat sink cooling system in [48] using natural and forced air cooling, as shown in Figure 15. The authors implemented an aluminium finned heat sink to the backside of the PV cells and applied the solar radiation ranging from 500 $\mathrm{W} / \mathrm{m}^{2}$ to $3000 \mathrm{~W} / \mathrm{m}^{2}$. The results indicate that the temperature of solar cells decreases by $5.4 \%$, and the electrical conversion efficiency increases by $8 \%$ when natural convection is used. In contrast, this value rises to $11 \%$, and the conversion efficiency increases by $16 \%$ when the heat sink is cooled by forced convection due to an increase of the heat transfer coefficient.

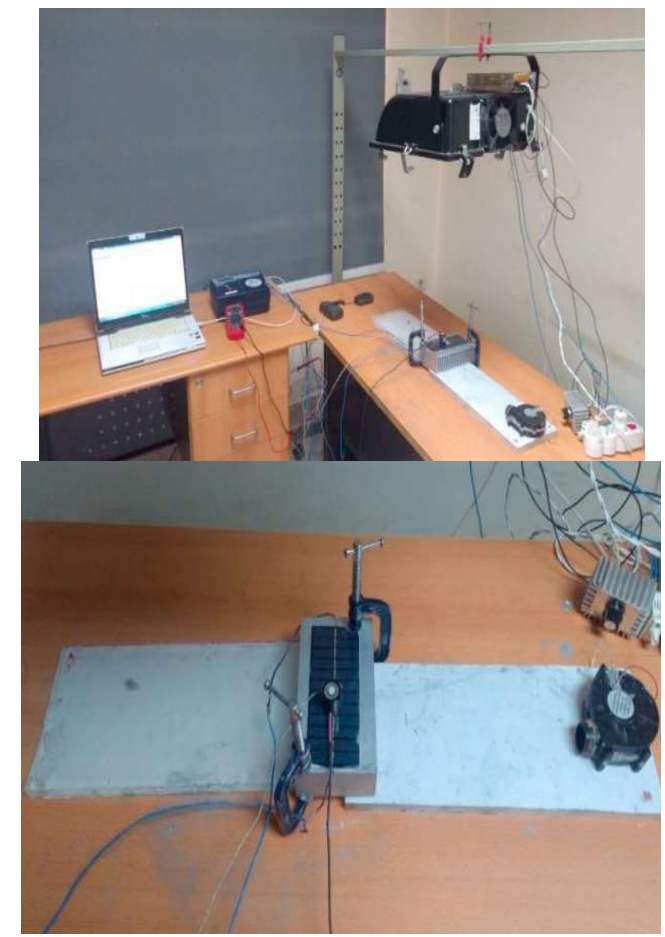

Fig. 15. The indoor experimental setup for heat sink cooling[48]

\section{Conclusions}

PV modules are affected by different factors, such as the age of the PV module, materials, atmospheric conditions and operating temperature. The temperature plays a crucial role amongst these parameters. The various cooling techniques used to improve the efficiency of PV modules are discussed in detail in this work. While the cooling of the PV modules enhances the thermal and electrical efficiency, it also maximises the life span of the PV panel and reduces the PV cell degradation.

From the reviewed papers and technologies, the following conclusions are obtained:

- The thermoelectric cooling technique uses the waste heat from the PV module effectively for enhancing efficiency. However, it has a low conversion efficiency rate and has a slow progression of technology.

- PV cooling with PCM and nanofluids decreased the operating temperature of the PV module and increased the electrical efficiency highly. The PCM stores the heat during the melting process, and it creates remarkable effects on the temperature. Ambient conditions highly manipulate the thermal management of PCM, and the capability of absorption of the material degrades over time. Although the nanofluids further enhance heat rejection from the PV module, the high cost of nanofluids utilisation is a drawback.

- PV modules cooled by forced water circulation enhance electrical efficiency; 
however, the flow rate of water kept constant, and it cannot reach the optimal efficiency.

- PV panel with water immersion cooling technique decreases the PV module temperature and improves the electrical efficiency. After a time, ionised water exposure influences the electrical efficiency of the module.

- The water spraying cooling technique shows a promising increase in efficiency and contributes to energy production; however, the water is wasted.

- PV cooling using heat sinks helps to reduce the operating temperature; however, the turbulent airflow makes the heat sinks unstable. In addition, the waste heat could be used for utilisation.

\section{References}

1. Wüstenhagen, R., Wolsink, M., Bürer, M.J., Energy Policy, Social acceptance of renewable energy innovation: An introduction to the concept., 35, 2683-2691, (2007).

2. Panwar, N.L., Kaushik, S.C., Kothari, S., Renew. Sustain. Energy Rev., Role of renewable energy sources in environmental protection: A review., 15, 1513-1524, (2011).

3. Dincer, I., Renew. Sustain. Energy Rev., Renewable energy and sustainable development: a crucial review., 4, 157-175, (2000).

4. Sargunanathan, S., Elango, A., Mohideen, S.T., Renew. Sustain. Energy Rev., Performance enhancement of solar photovoltaic cells using effective cooling methods: A review., 64, 382-393, (2016).

5. M., Entchev, E., Yang, L., Alexandria Eng. J., Inclusive analysis and performance evaluation of solar domestic hot water system (a case study)., 56, 201-212, (2017).

6. Chatterjee, S., Tamizhmani, G., Conf. Rec. IEEE Photovolt. Spec. Conf., BAPV arrays: Side-by-side comparison with and without fan cooling., 38, 537542, (2012).

7. Bashir MA, Ali HM, Amber KP, Bashir MW, Ali $\mathrm{H}$, Imran $\mathrm{S}$, et al., Thermal Science, Performance Investigation of Photovoltaic Modules by Back Surface Water Cooling, 22, 2401-2411, (2018).

8. Simon, M., Meyer, E.L., Sol. Energy Mater. Sol. Cells, Detection and analysis of hot-spot formation in solar cells., 94, 106-113, (2010).

9. Swapnil Dubey, Jatin Narotam Sarvaiya, Bharath Seshadri, Energy Procedia, Temperature Dependent Photovoltaic (PV) Efficiency and Its Effect on PV Production in the World - A Review, 33, 311-321, (2013).

10. Amin, N., Lung, C.W., Sopian, K., Renew. Energy, A practical field study of various solar cells on their performance in Malaysia, 34, 1939-1946, (2009).
11. M. S. Khan, V. Hegde and G. Shankar, International Conference on Current Trends in Computer, Electrical, Electronics and Communication (CTCEEC), Effect of Temperature on Performance of Solar Panels- Analysis, 109-113, (2017).

12. N. H. Zaini, M. Z. Ab Kadir, M. Izadi, N. I. Ahmad, M. A. M. Radzi and N. Azis, IEEE Conference on Energy Conversion (CENCON), The effect of temperature on a mono-crystalline solar PV panel, 249-253, (2015).

13. K Nishioka, T Hatayama, Y Uraoka, T Fuyuki, R Hagihara, M Watanabe, Solar Energy Materials and Solar Cells, Field-test analysis of PV system output characteristics focusing on module temperature, 75 , 665-671, (2003).

14. R. Dubey et al., IEEE 42nd Photovoltaic Specialist Conference (PVSC), Measurement of temperature coefficient of photovoltaic modules in field and comparison with laboratory measurements, 1-5, (2015).

15. G. Colt, International Conference on Applied and Theoretical Electricity (ICATE), Performance evaluation of a PV panel by rear surface water active cooling, 1-5, (2016).

16. Sahay A, Sethi VK, Tiwari AC, Pandey M., Renew Sustain Energy Rev, A review of solar photovoltaic panel cooling systems with special reference to Ground Coupled Central Panel Cooling System (GC-CPCS)., 42, 306-312, (2014).

17. Royne A, Dey CJ, Mills DR., Sol Energy Mater Sol Cells, Cooling of photovoltaic cells under concentrated illumination: a critical review., 86, 451-483, (2003).

18. N. Papanikolaou, G. Maliaris, M. Loupis, A. Kyritsis and V. Nikolaidis, MedPower, Combination of building applied PV panels with thermoelectric generation and geothermal cooling., 43, 1-5, (2014).

19. Hasan, A.; McCormack, S.J.; Huang, M.J.; Norton, B., Energies, Energy and Cost Saving of a Photovoltaic-Phase Change Materials (PV-PCM) System through Temperature Regulation and Performance Enhancement of Photovoltaics., 7, 1318-1331, (2014)

20. Rok Stropnik, Uroš Stritih, Renewable Energy, Increasing the efficiency of PV panel with the use of PCM, 97, 671-679, (2016).

21. Anna Machniewicz, Dominika Knera, Dariusz Heim, Energy Procedia, Effect of Transition Temperature on Efficiency of PV/PCM Panels, 78, 1684-1689, (2015).

22. Munzer.S.Y. Ebaid, Ayoup.M. Ghrair, Mamdoh Al-Busoul, Energy Conversion and Management, Experimental investigation of cooling photovoltaic (PV) panels using (TiO2) nanofluid in water polyethylene glycol mixture and (A12O3) nanofluid in water- cetyltrimethylammonium bromide mixture, 155, 324-343, (2018). 
23. Zakie Rostami, Masoud Rahimi, Neda Azimi, Energy Conversion and Management, Using highfrequency ultrasound waves and nanofluid for increasing the efficiency and cooling performance of a PV module, 160, 141-149, (2018).

24. H. Bahaidarah, Abdul Subhan, P. Gandhidasan, S. Rehman, Energy, Performance evaluation of a PV (photovoltaic) module by back surface water cooling for hot climatic conditions, 59, 445-453, (2013).

25. Shuang-Ying $\mathrm{Wu}$, Chen Chen, Lan Xiao, Renewable Energy, Heat transfer characteristics and performance evaluation of water-cooled $\mathrm{PV} / \mathrm{T}$ system with cooling channel above PV panel, 125, 936-946, (2018).

26. Li Zhu, Robert $\mathrm{F}$ Boehm, Yiping Wang, Christopher Halford, Yong Sun, Solar Energy Materials and Solar Cells, Water immersion cooling of PV cells in a high concentration system, 95, 538545, (2011).

27. Yiping Wang, Zhenlei Fang, Li Zhu, Qunwu Huang, Yan Zhang, Zhiying Zhang, Applied Energy, The performance of silicon solar cells operated in liquids, 86, 1037-1042, (2009).

28. Faruk Yesildal, Ahmet Numan Ozakin, Kenan Yakut, Engineering Science and Technology, Optimisation of operational parameters for a photovoltaic panel cooled by spray cooling, (2021).

29. Opeyeolu Timothy Laseinde, Moyahabo Dominic Ramere, Procedia Computer Science, Improvement in polycrystalline solar panel using thermal control water spraying cooling, 180, 239-248, (2021).

30. Cătălin George Popovici, Sebastian Valeriu Hudişteanu, Theodor Dorin Mateescu, NeluCristian Cherecheş, Energy Procedia, Efficiency Improvement of Photovoltaic Panels by Using Air Cooled Heat Sinks, 85, 425-432, (2016).

31. A.M. Elbreki, A.F. Muftah, K. Sopian, H. Jarimi, A. Fazlizan, A. Ibrahim, Case Studies in Thermal Engineering, Experimental and economic analysis of passive cooling PV module using fins and planar reflector, 23, 100801, (2021).

32. Abdallah Y.M. Ali, Essam M. Abo-Zahhad, Hesham I. Elqady, Mohammed Rabie, M.F. Elkady, A.H. El-Shazly, Energy Reports, Impact of microchannel heat sink configuration on the performance of high concentrator photovoltaic solar module, 6, 260-265, (2020).

33. Yildirim, M.A.; Nowak-Ocłon, M., Energies, Modified Maximum Power Point Tracking Algorithm under Time-Varying Solar Irradiation., 13, 6722, (2020).

34. Tawanda Hove, Renewable Energy, A method for predicting long-term average performance of photovoltaic systems, 21, 207-229, (2000).

35. Kiflemariam R, Almas M, Lin C., Proceedings of the COMSOL conference in Boston, Modeling integrated thermoelectric generator photovoltaic thermal (TEG-PVT) system, (2014).
36. Moshfegh H., Eslami M., Hosseini A., Springer, Thermoelectric Cooling of a Photovoltaic Panel. In: Nižetić S., Papadopoulos A. (eds) The Role of Exergy in Energy and the Environment. Green Energy and Technology.

37. Ángel A. Bayod-Rújula, Amaya Martínez-Gracia, Alejandro Del Amo, Marta Cañada, Sergio Usón, Javier Uche, Juan A. Tejero, RE\&PQJ, Integration of Thermoelectric generators (TEG) in Solar PVT panels, 17, 495-499, (2019).

38. Mehmet Esen, Solar Energy, Thermal performance of a solar-aided latent heat store used for space heating by heat pump, 69, 15-25, (2000).

39. S.S. Chandel, Tanya Agarwal, Renewable and Sustainable Energy Reviews, Review of cooling techniques using phase change materials for enhancing efficiency of photovoltaic power systems, 73, 1342-1351, (2017).

40. M.J. Huang, P.C. Eames, B. Norton, Solar Energy, Phase change materials for limiting temperature rise in building integrated photovoltaics, 80,1121 1130, (2006).

41. Tingyu Wang, Shuangfeng Wang, Ruilian Luo, Chunyu Zhu, Tomohiro Akiyama, Zhengguo Zhang, Applied Energy, Microencapsulation of phase change materials with binary cores and calcium carbonate shell for thermal energy storage, 171, 113-119, (2016).

42. S.A. Nada, D.H. El-Nagar, Renewable Energy, Possibility of using PCMs in temperature control and performance enhancements of free stand and building integrated PV modules, 127, 630-641, (2018).

43. Nooshin Karami, Masoud Rahimi, Energy Conversion and Management, Heat transfer enhancement in a PV cell using Boehmite nanofluid, 86, 275-285, (2014).

44. Shuang-Ying $\mathrm{Wu}$, Chen Chen, Lan Xiao, Renewable Energy, Heat transfer characteristics and performance evaluation of water-cooled PV/T system with cooling channel above PV panel, 125, 936-946, (2018).

45. H. Bahaidarah, Abdul Subhan, P. Gandhidasan, S. Rehman, Energy, Performance evaluation of a PV (photovoltaic) module by back surface water cooling for hot climatic conditions, 59, 445-453, (2013).

46. Mehrotra S, Rawat P, Debbarma M, Sudhakar K., Int J Sci Environmental Technology, Performance of a solar panel with water immersion cooling technique., 3, 1161-1172, (2014).

47. S. Nižetić, D. Čoko, A. Yadav, F. Grubišić-Čabo, Energy Conversion and Management, Water spray cooling technique applied on a photovoltaic panel: The performance response, 108, 287-296, (2016).

48. Aly M.A. Soliman, Hamdy Hassan, Shinichi Ookawara, Energy Procedia, An experimental study of the performance of the solar cell with heat sink cooling system, 162, 127-135, (2019). 